\title{
Industrias de buriles en el Pleistoceno de los Andes
}

EDWARD P. LANNING

\section{RESUMEN}

Los complejos arqueológicos Exacto, Ayacucho y Oquendo, del Ecuador y Perú, pertenecen a una tradición lítica marcada por buriles de tecnología compleja. Elementos de esta tradición se encuentran en Chile en el Complejo Chuqui tardio. Dos sitios de la sierra ecuatoriana, El Inga y San José, probablemente fueron ocupados también por gente de esta tradición. El Complejo Ayacucho está fechado en 14.180-14.190 años AP, y los demás probablemente son de la misma o de mayor antigüedad.

Se postula: 1) La llegada en Norteamérica de una tecnología del Paleolítico Superior; 2) La transmisión de esta tradición hacia los Andes hace alrededor de 15.000 o 15.000 años; 3) El empobrecimiento progresivo de las tecnologías de buriles y láminas; y 4) La desaparición de la tradición hace poco menos de 14.000 años, cuando fue reemplazada por la tradición de bifaces.

I have recently suggested the name "Burin Tradition" for a number of interrelated lithic assemblages in Ecuador, Peru, and Chile (Lanning Ms). These include the Exacto Complex of coastal Ecuador, the Oquendo Complex of coastal Peru, the Ayacucho Complex of highland Peru, and, peripherally, part of the Chuqui Complex of the Atacama Desert. Part of the mixed assemblage at El Inga in the Ecuadorian highlands may also belong to this tradition, as may the San José site of the same region.

The first Andean burins were discovered by Robert E. Bell and William Mayer-Oakes at El Inca in 1960. Bell excavated in the site in 1961, amassing more burins as well as projectile points and other materials of various periods. The first pure components of the Burin Tradition were found by Thomas C. Patterson and myself in the Cerros de Oquendo, Chillón Valley, late in 1962. Subsequent research has included the exploration of Exacto sites in 1964 by the First Columbia University
Expedition to Ecuador; the discovery of the San José site in 1965 by Mayer-Oakes and Joan B. Townsend; exploration of Chuqui sites in 1966 by the Columbia University Field Station in Calama; excavation of these sites in 1969 by Bruce Grove of the Field Station; and excavation of the Ayacucho layer at Pikimachay Cave in 1969 by Richard S. MacNeish.

Pikimachay Cave is the most important known site of the Burin Tradition. This cave is located in the Huanta Valley near Ayacucho, Peru, and was excavated by MacNeish in mid 1969. The deepest layer, sealed in under a rock fall from the roof of the cave, yielded 51 artifacts, bones of at least Paleolama and Megatherium, and three radiocarbon dates: $14.180 \pm 300 ; 14.180 \pm 250$, and $14.190 \pm 180$ BP (UCLA laboratory numbers not yet available). Artifacts, designated Ayacucho Complex, are of basalt and flint. They include large simple and dihedral burins; choppers; fluted wedges; and notched pieces and denticulates made on large flakes. According to MacNeish, the flakes have large, wide-angle striking platforms like those found throughout the Andes in components of the Biface Tradition. The association of artifacts, faunal remains, and radiocarbon samples are impeccable, since all come from a single thin occupation layer immediately buried under massive chunks of rock fallen from the cave roof (MacNeish Ms, personal communication).

Very similar to Ayacucho in artifact inventory, and probably contemporary with it, are the five sites of the Exacto Complex on the Santa Elena Peninsula of the Ecuadorian coast. All of the Ayacucho types are found here, executed in Santa Elena chert, and the specimens are of the same large dimensions (Figs. 1-3). Core technique is somewhat different, since Exacto flakes tend toward right-angle striking platforms, but this difference may be due to the use of different raw materials. Bladelets and microblade cores, which occur in small numbers, have not yet been reported from the Ayacucho complex (Lanning 1967a: 10). 
EDWARD P. LANNING

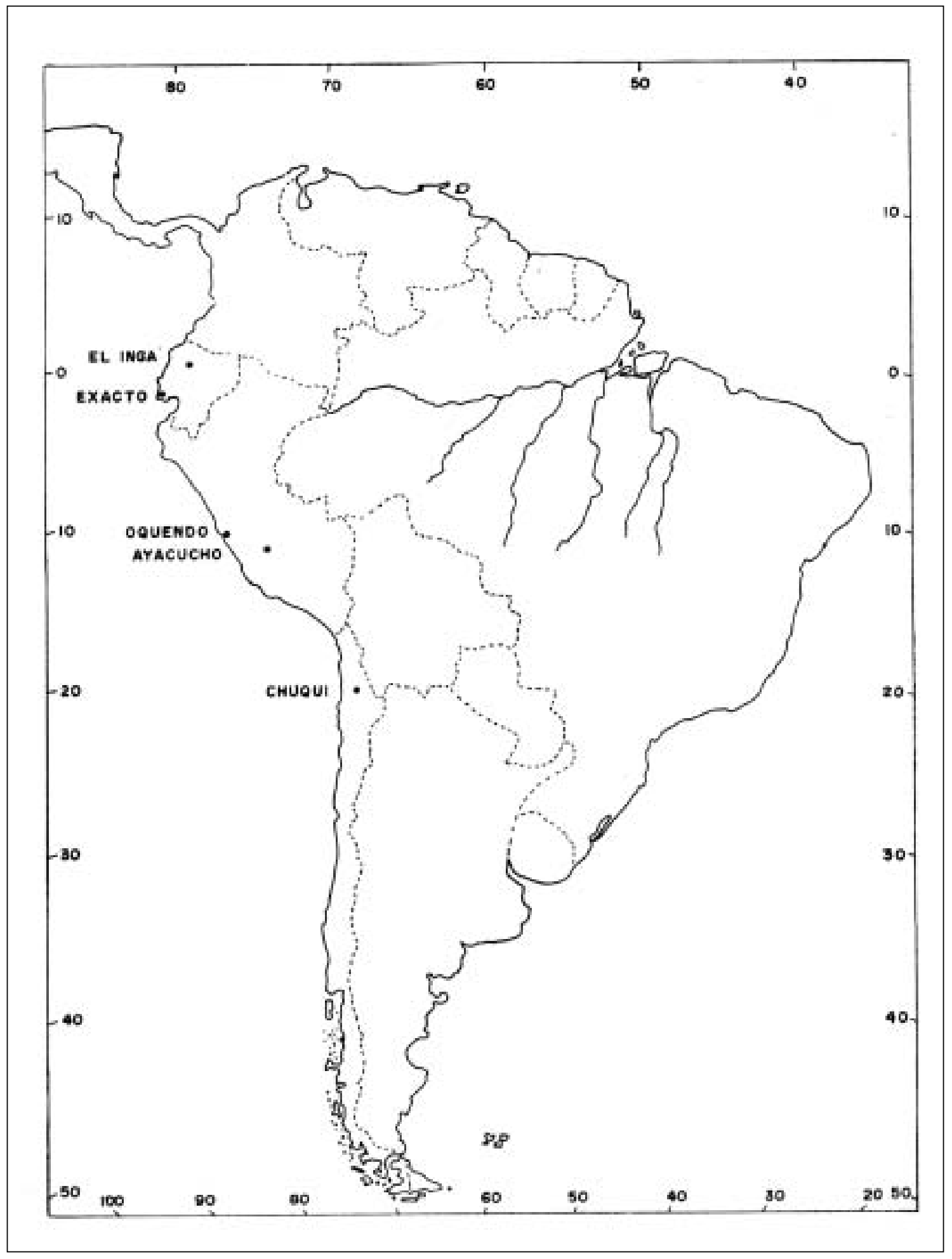

Map 1. Location of archaeological complexes and sites attributed to the Burin Tradition 

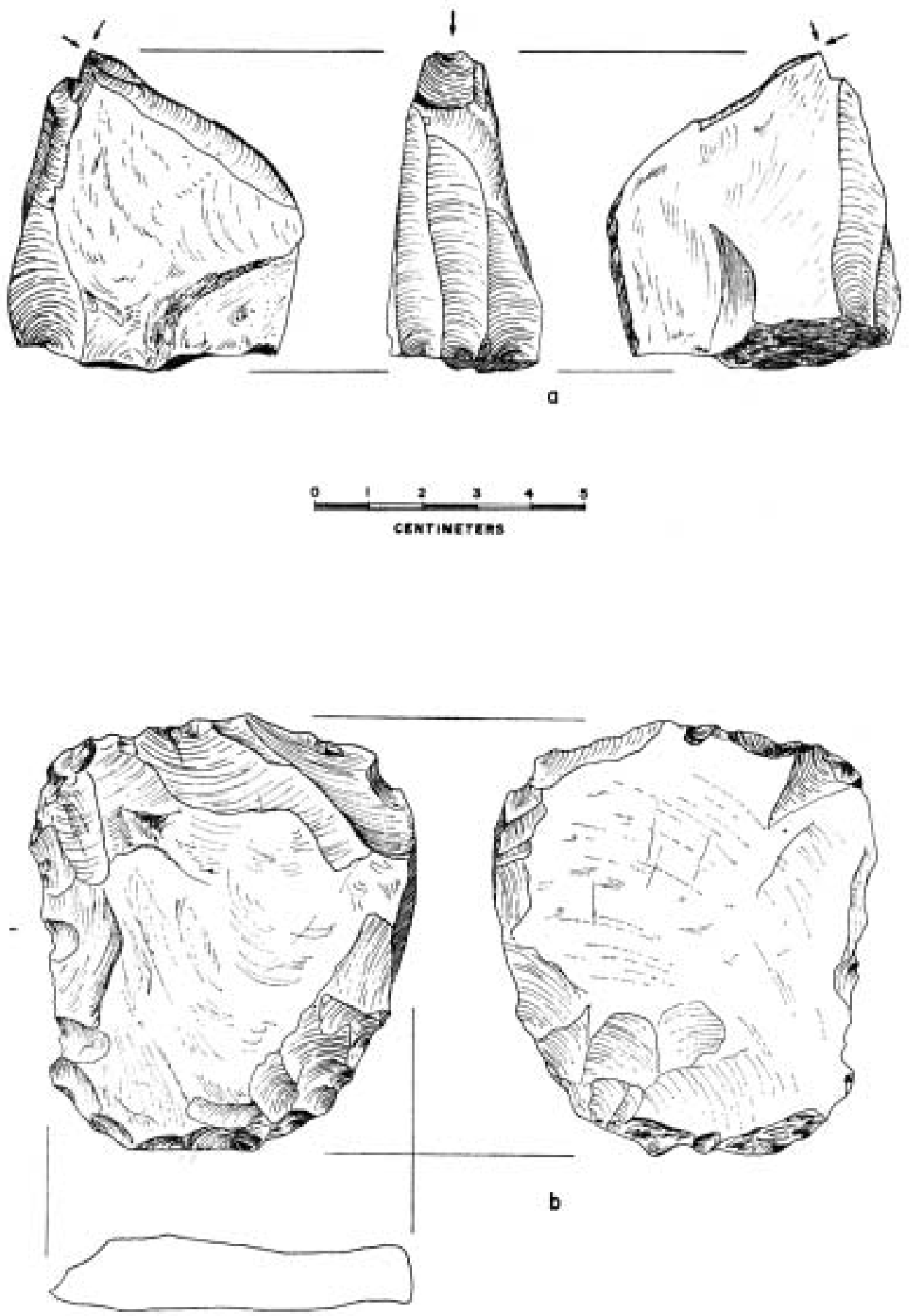

Figure 1. Exacto artifacts, chert. a) Dihedral burin on microblade core; b) Retouched flake 

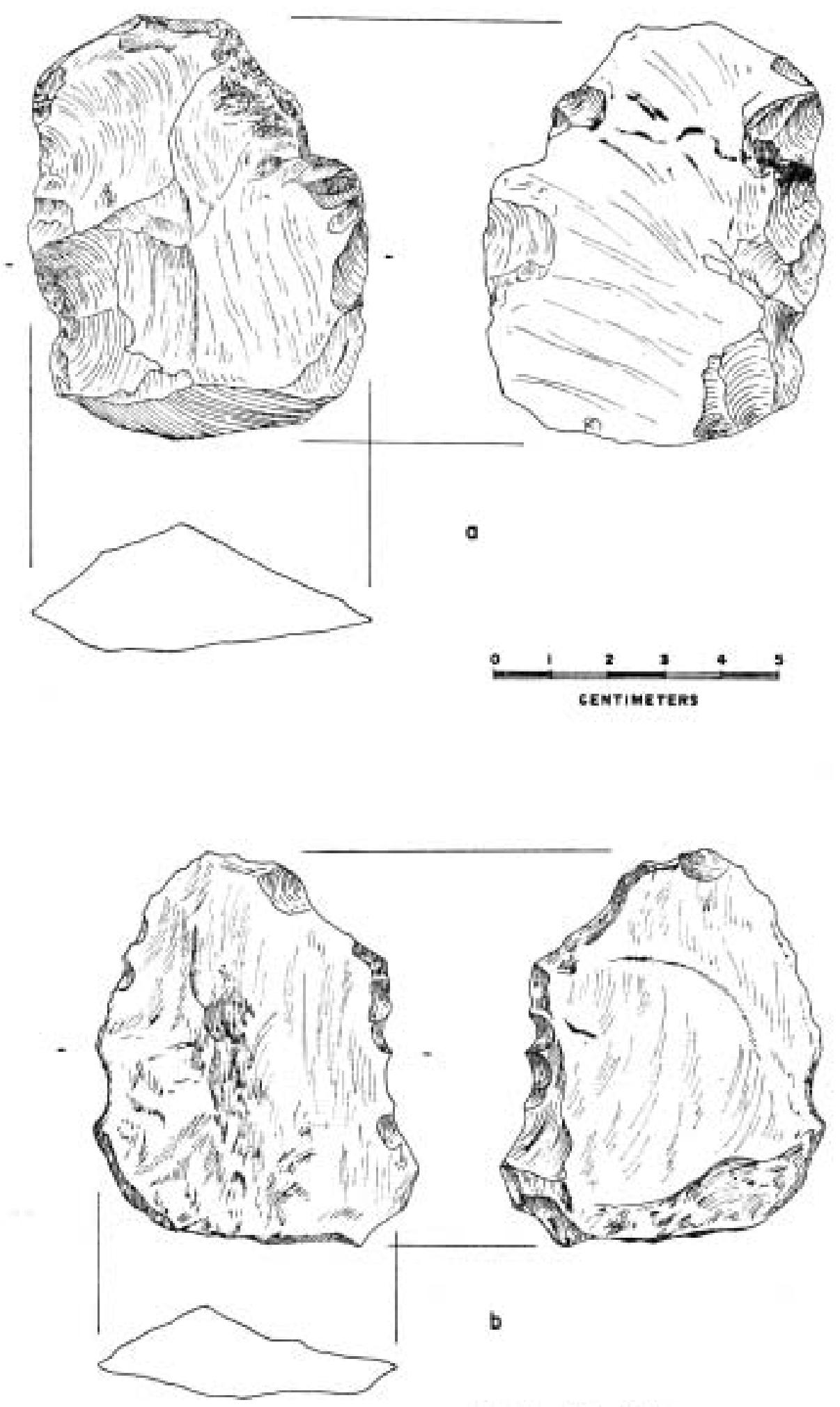

Figure 2. Exacto artifacts, chert. a) Notched piece; b) Denticulate 


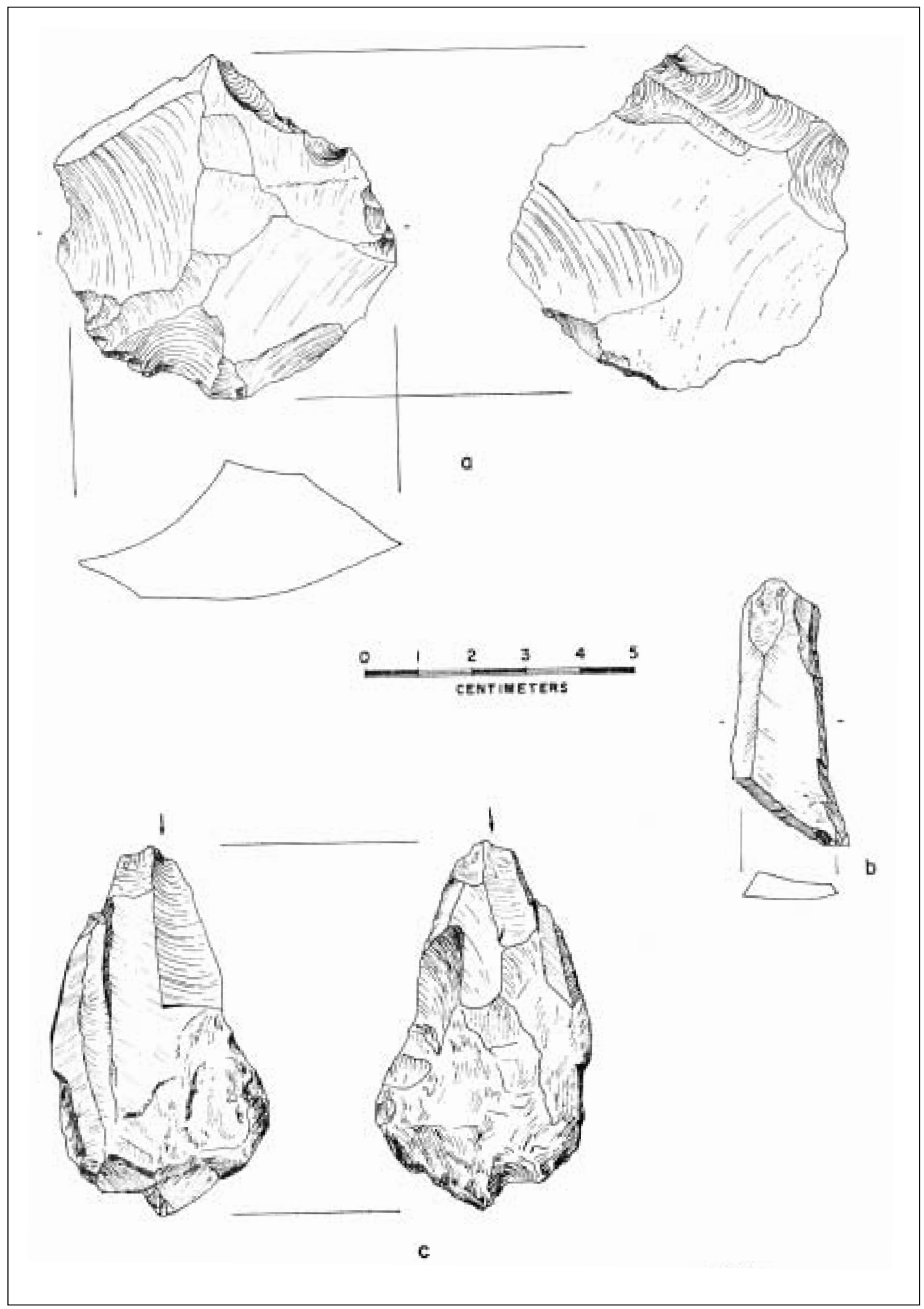

Figure 3. Exacto artifacts, chert. a) Notched piece on microblade core; b) bladelet; c) Fluted wedge 
The other components of the Burin Tradition differ considerably in core and burin technology, but all are linked to Ayacucho and Exacto by the basic inventory of simple and dihedral burins, notched pieces, and denticulates.

Oquendo artifacts are all made of very finegrained quartzite. Though simple and dihedral burins are present, the favorite form -making up nearly $50 \%$ of all artifacts- is the durin made on retouched truncation. Refinements such as side-edge retouch and stop notches indicate a more sophisticated technology of burin manufacture. Oquendo burins and flake tools are typically smaller than those of Exacto and Ayacucho. Microblade cores and bladelets are more abundant than in Exacto, but are still typically unretouched. There are no choppers or fluted wedges. A few skewed scrapers and becs burinants made by reverse lateral retouch represent new elements not present in Exacto or Ayacucho. Artifacts, whether made on flakes or cores, tend to be short and chunky as a consequence of the original form of the raw material (Figs. 4-5) (Lanning 1963: 171, 1967c: 41-42, 1967d: 12-13; Lanning and Patterson 1967: 48-49).

Certain of the archaeological sites at the Salar de Talabre in the Atacama Desert, assigned to the Chuqui Complex, show typological similarities to Oquendo. These sites have all been seriated late in Bruce Grove's tentative chronology for the Chuqui Complex, whereas his early Chuqui sites more resemble the Red Zone Complex of Peru in their artifact inventories. The following remarks are based on the collection from our site RAnL-68B, which falls at or near the end of Grove's sequence. Artifacts are made of welded tuff, silicified limestone, and low-grade chert. They average about the same size as Oquendo artifacts, but are typically made on little flat nodules rather than on flakes or cores (Figs. 6-7). Most of them are simple scraper-like tools made by steep lateral retouch, unlike the artifacts of other components of the burin Tradition but resembling those from such hypothetically earlier assemblages as early Chuqui and the Red Zone. Next in frequency are becs burinants like those found in Oquendo, and notched pieces. Denticulates, universal in other Burin Tradition components, are absent. Burins, though not common, include all three classes: simple, dihedral, and made on retouched truncations. They do not show either side-edge retouch or stop notches. Because of technical difficulties inherent in the use of whole nodules rather than flages, burin spall scars are typically much shorter than in Oquendo. There are no choppers, fluted wedges, microblade cores, or bladelets in any Chuqui site (Lanning 1967; Grove Ms).

El Inga and San José, the two sites in the central Ecuadorian highlands tentatively assigned to the Burin Tradition, both present problems of identification. I have not had opportunity to see artifacts from San José. My only information is Mayer-Oakes' statement that it "provides an obsidian industry much like El Inga with the exception that bi-faces (i.e. projectile points) are lacking..." (Mayer-Oakes Ms: 1). It the similarities are really close, perhaps the burins and related artifacts at El Inga should be interpreted as a component of the San José Complex, artificially mixed with post-Pleistocene materials.

It is precisely the possibility of such mixture that leads me to view the El Inga burins as an unsolved problem. It there is a pre-projectile point component at El Inga, it should include at least the burins, the blade knives, the notched and strangulated blades, and the unusual speciment that Bell calls "concave scraper-burin cores" (Bell 1965: 176-279, 288-303; Mayer-Oakes 1963). The burins show the full range of sophisticated Oquendo tecnology, including dihedrals, retouched truncations, side-edge retouch, and stop notches. The blades, if they merit the name, are percussion-struck and apparently not from polyhedral cores (Bell 1965: 276-277). Happily most of the specimens are of obsidian, so that measurements of hydration layers should soon determine whether or not they are actually older than the projectile point from the site (Fig. 8).

Assuming that San José belongs to the Burin Tradition, and that the burins, retouched blades, and related artifacts from El Inga represent a San José component mechanically mixed with later materials, we can venture a few hypothesis about the antiquity, internal relationships, and ancestry of the various components of the Burin Tradition.

There is no reason to doubt the validity of the radiocarbon dates from Pikimachay Cave, which place the Ayacucho Complex in the vicinity of $14.200 \mathrm{BP}$. Exacto is sufficiently similar to Ayacucho that the two were probably 

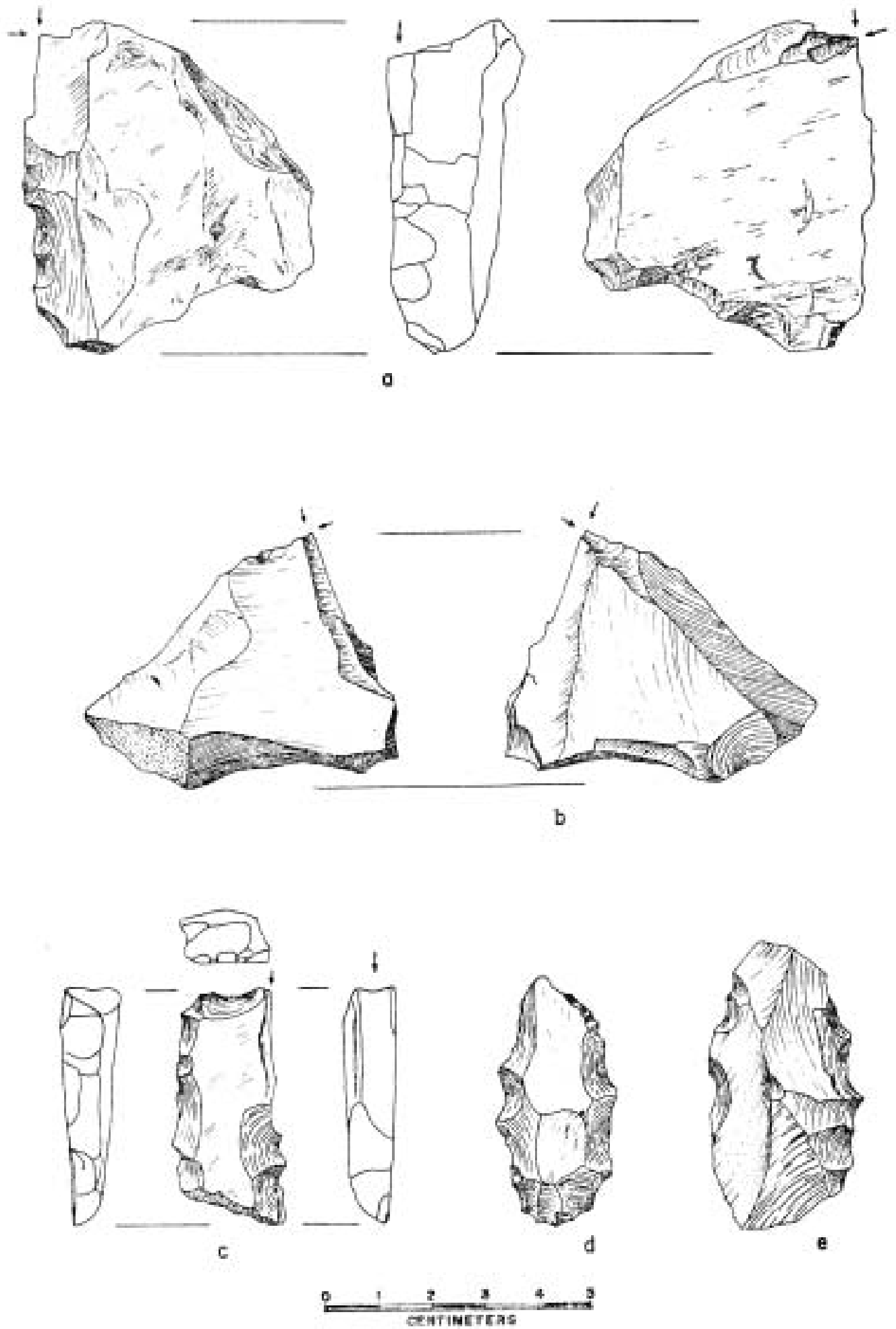

Figure 4. Oquento artifacts, quartzite. a) Dihedral burin with some end retouch; b) Dihedral burin; c) Burin on retouched truncation; d) Denticulate; e) Denticulate 

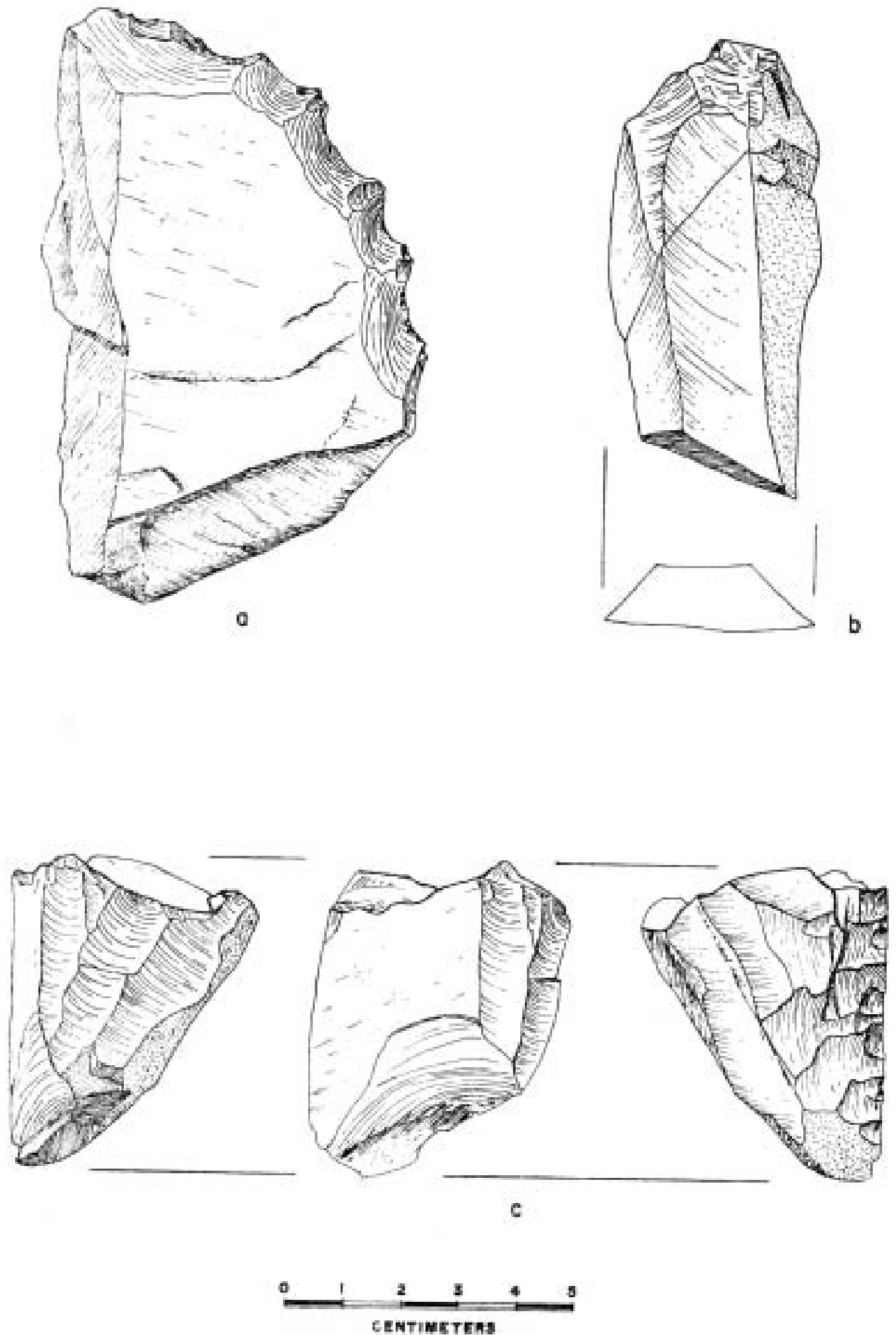

Figure 5. Oquento artifacts chert. a) Denticutale; b) Blade; c) Scraper on microblade core 

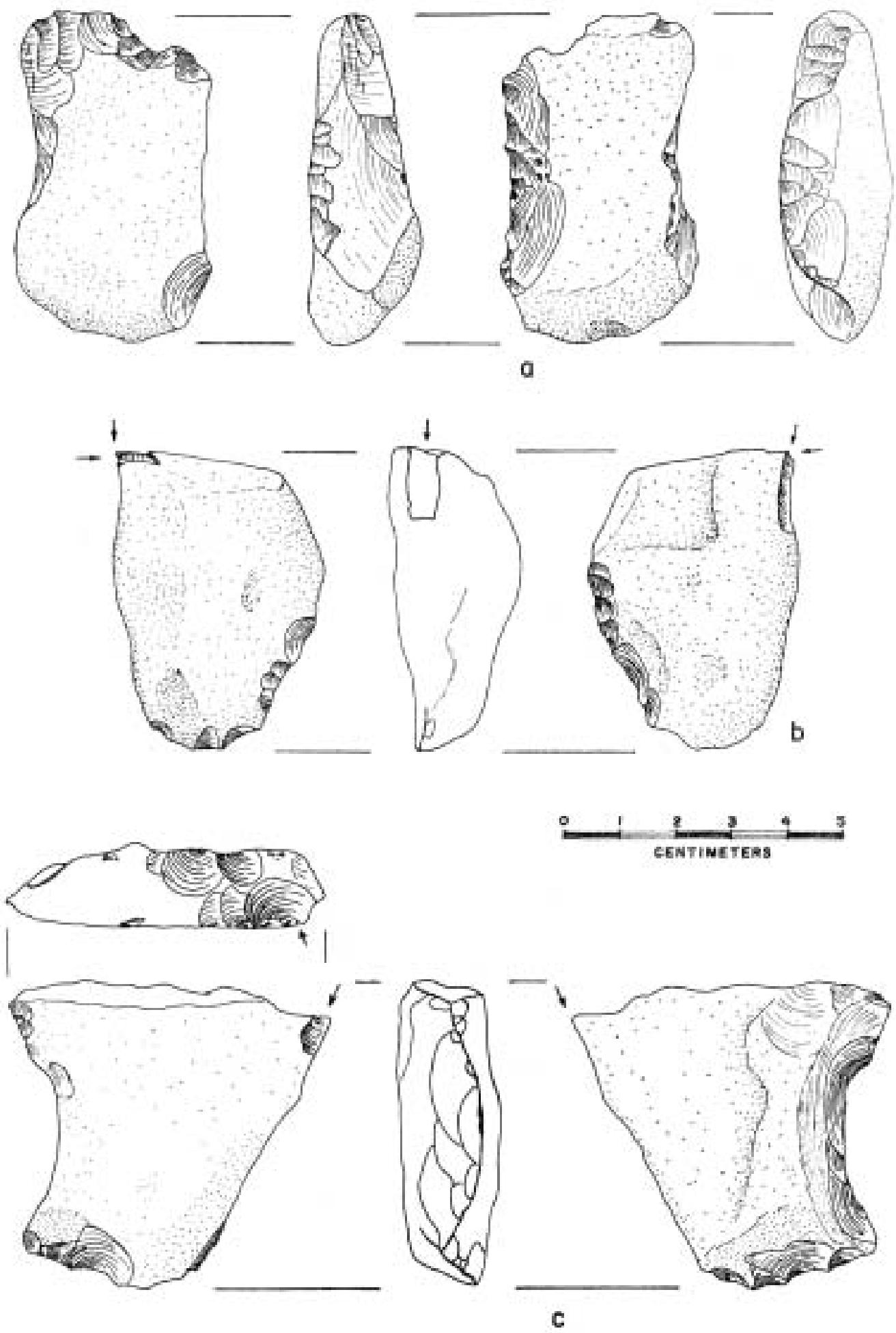

Figure 6. Chuqui artifacts, a-b) silicified limestone, c) welded tuff. a) Bec burinant; b) Dihegral burin; c) Burin on retouched truncation 


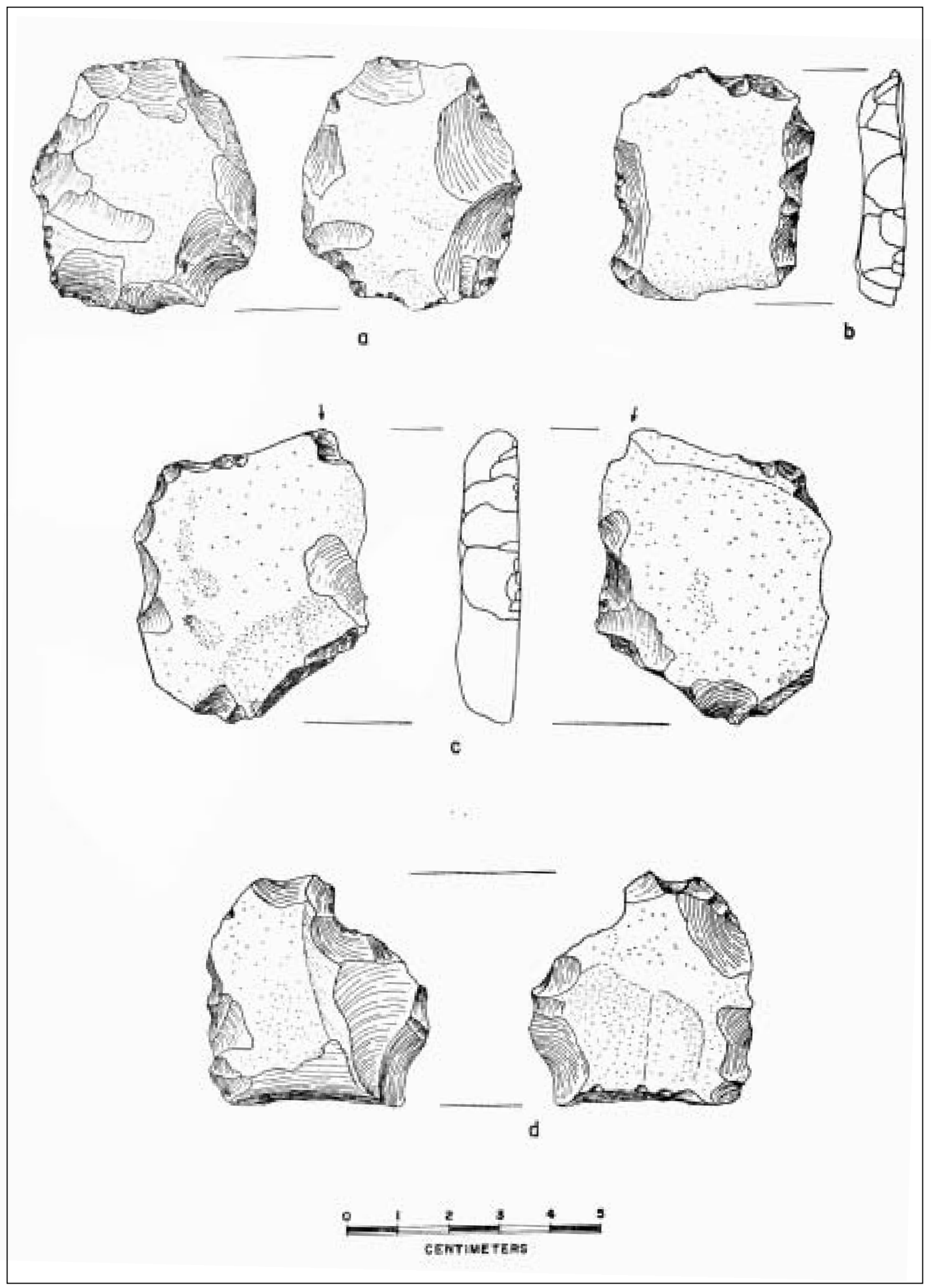

Figure 7. Chuqui artifacts, a, c-d) welded tuff, b) silicified limestone. a) Retouched nodule; b) Notched piece and craper; c) Simple burin; d) Notched piece 


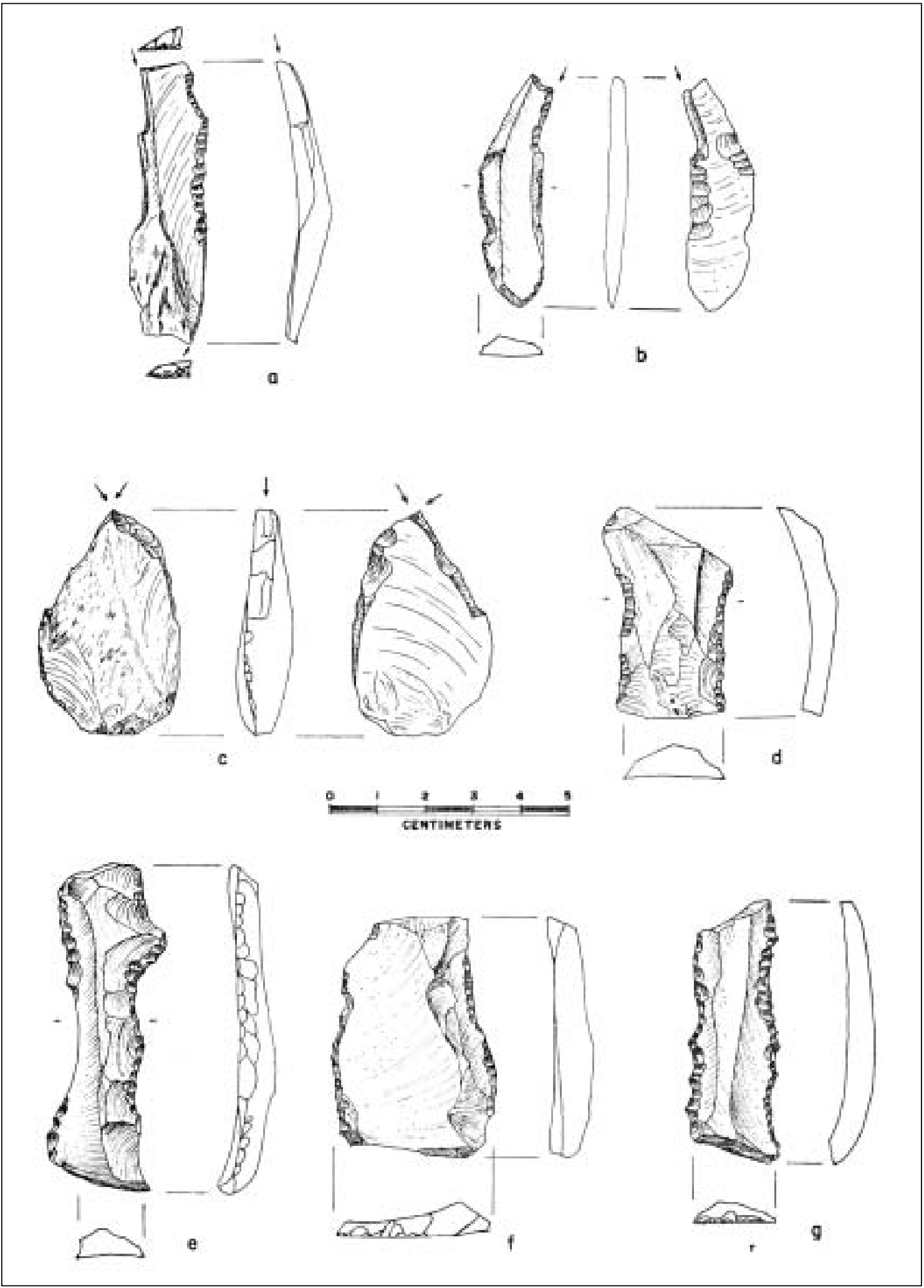

Figure 8. El Inga artifacts, obsidian. a) Double burin on retouched truncation; b) Burin on retouched truncation; c) Dihedral burin; d) Retouched blade fragment; e) Notched blade; f) Retouched blade fragment; g) Denticulated blade fragment 
approximately contemporary. These are the only two known assemblages with only simple and dihedral burins. If the components with burins on retouched truncations are not contemporary local variations, I suspect that they are still earlier. I have only a very tenuous reason for this hypothesis. As indicated above, Ayacucho core technology and flaketool typology are very similar to those of the Biface Tradition. The only radiocarbon date for a pure Biface Tradition component is $10.430 \pm 160 \mathrm{BP}$ for the end of Chivateros I on the Peruvian coast (Lanning 1967c: 44). This date, should it prove valid, suggests that the Biface Tradition was more recent than the Burin Tradition in the Andes. If Ayacucho is most similar to the Biface Tradition, then other components of the Burin Tradition -especially those least similar to Ayacucho and to the Biface Tradition- could be earlier. I would therefor like to postulate an earlier group of Burin Tradition components, perhaps dating around 15.000-16.000 $\mathrm{BP}$, including Oquendo and San José-El Inga; and a later group dating around $14.000 \mathrm{BP}$, including Ayacucho and Exacto. Late Chuqui is too different from the other assemblages to hazard placing it in this scheme.

If we view the burins and retouched blades from El Inga as a late Pleistocene industry, divorced from the projectile points, skin scrapers, and other
post-Pleistocene elements, the burin-blade industry becomes recognizable as a typical, if somewhat impoverished, Upper Paleolithic assemblage. The similarities seem to me to rule out any possibility other than historical continuity. If, there is any truth to our hypothesis that the burins and blade tools are earlier than the projectile points, then we should concede direct Asian ancestry to the El Inga burins and blades. If no similar industry has yet been reported from North America, it is only because Paleoindian research in North America has not been oriented toward its discovery.

The remaining components can be viewed as technologically impoverished offshoots of San José-El Inga: Oquendo through loss of blades as blanks for burins and retouched tools; Late Chuqui through additional loss of stop notches and retouched side edges (perhaps because they were not feasible for working whole nodules); Exacto and Ayacucho through loss of all of these techniques and also of retouched end truncations.

In summary, I postulate: 1) the spread into North America of a typical Upper Paleolithic technology and tool kit; 2) the arrival of this tradition in the Andes about 15.000 or 16.000 years ago; 3) progressive impoverishment of burin and blade technologies; and 4) their replacement shortly after 14.000 BP by the Biface Tradition.

\section{BIBLIOGRAPHY}

BELL, R. E., 1965. Archaeological investigations at the site of El Inga, Ecuador. Editorial Casa de la Cultura Ecuatoriana, Quito.

GROVE, B., Ms. Some late Pleistocene lithic assemblages from western South America. New Haven, 1969.

LANNING, E. P., 1963. Las culturas precerámicas de la costa central del Perú. Letras, Organo de la Facultad de Letras de la Universidad Nacional de San Marcos, $\mathrm{n}^{\text {os }} 70-71$, pp. 168-176. Lima.

-1167a. Archaeological investigations on the Santa Elena Peninsula, Ecuador. Report to the National Science Foundation on research carried out under Grant GS-402, 1964-1965. Columbia University, New York.

-1967b. Informe previo de las investigaciones realizadas por la Columbia University Field Station durante el año 1966. Universidad del Norte, Instituto de Ciencias Sociales, Boletín Informativo 4. Antofagasta.
_ 1967c. Peru before the Incas. Prentice-Hall, Englewood Cliffs.

— 1967d. Preceramic archaelogy of the Ancón-Chillón region, central coast of Peru. Report to the National Science Foundation on research carried out under Grant GS-869, 1965-66. Columbia University, New York.

-Ms. Lithic traditions in the Pleitocene of South America. New York, 1969.

LANNING, E. P., y T. C. PATTERSON, 1967 Early man in South America. Scientific American 217 (5): 44-50.

MACNEISH, R. S., Ms. The first annual report of the Archaeological-Botanical Expedition to the AyacuchoHuanta Region of Highland Peru. Andover, 1969.

MAYER-OAKES, W. J. 1963. Early man in the Andes. Scientific American 208 (5): 117-128.

_Ms. Obsidian flake studies. Winnipeg, 1966. 